\title{
Increase In Macro Nutrients By Adding Banana Waste To Liquid Organic Fertilizer
}

\author{
Hendrawani $^{1)}$, Husnul Hatimah ${ }^{2)}$, dan Hulyadi ${ }^{3)}$ \\ 1,2,3 Dosen Program Studi Pendidikan Kimia, FSTT, UNDIKMA \\ Corresponding Author: hulyadi@ikipmataram.ac.id
}

\begin{abstract}
Liquid organic fertilizer is a solution from the fermentation of organic materials by involving microorganisms as a destructor of macromolecular compounds into minerals that are easily absorbed by plants. The quality of organic fertilizers is the main ingredient to get productive plants. The quality of organic fertilizer is determined by the concentration of macro nutrients such as nitrogen $(\mathrm{N})$, potassium $(\mathrm{K})$, and phosphorus. Getting high amounts of macronutrients fertilized organically is not easy. Macronutrients in organic waste with high concentrations are very difficult to obtain because each organic waste does not have all three macro-nutrients simultaneously. It takes a combination of organic waste to increase the concentration of macro nutrients in organic fertilizers. The combination of tofu whey with banana waste is one technique to obtain organic fertilizers that are high in phosphorus content. This study aims to obtain the effect and conditions of fermentation on the addition of mass of banana waste to produce optimum levels of phosphorus $(\mathrm{P})$ in liquid fertilizer of tofu waste. The type of research used is pre-experimental research. The design of this study used a completely randomized design (CRD) with two factors, namely the first factor was the mass of banana waste $(X)(X 1=250$ grams, $X 2=500$ grams, $\mathrm{X} 3=750$ grams $)$ and the second factor was the fermentation time $(\mathrm{Y})(\mathrm{Y} 1=14$ days, $\mathrm{Y} 2=28$ days, $\mathrm{Y} 3=$ 42 days). Determination of phosphorus content using UV-Vis spectroscopy instrument. Parameters measured were phosphorus $(\mathrm{P})$ levels in liquid organic fertilizer. The independent variables in this study were the mass of banana waste and fermentation time, while the dependent variable in this study was the phosphorus content of the liquid fertilizer produced. The results of the analysis show that the phosphorus content $(\mathrm{P})$ produced is $\mathrm{X} 1 \mathrm{Y} 1=0.1 \%, \mathrm{X} 2 \mathrm{Y} 1=0.5 \%, \mathrm{X} 3 \mathrm{Y} 1=0.09 \%, \mathrm{X} 1 \mathrm{Y} 2=0.5 \%, \mathrm{X} 2 \mathrm{Y} 2=2 \%, \mathrm{X} 3 \mathrm{Y} 2$ $=1.9 \%, \mathrm{X} 1 \mathrm{Y} 3=0.2 \%, \mathrm{X} 2 \mathrm{Y} 3=0.5 \%$ and $\mathrm{X} 3 \mathrm{Y} 3=0.5 \%$. There is an effect with the addition of a mass of banana waste as much as 250 grams at a 12-day fermentation time. It can be concluded that the liquid fertilizer produced has exceeded the SNI quality standard.
\end{abstract}

Keywords: Banana Waste, macro nutrients 


\section{PENDAHULUAN}

Limbah organik merupkan bahan organik dari tumbuhan dan hewan yang terbuang kebadan air tampa melalui proses pengolahan. Dampak yang muncul dari pembuangan limbah organik kebadan air adalah menurunnya kualitas air. Dampak yang biasanya teramati secara langsung adalah terbentuknya ledakan populasi lumut dan timbulnya aroma busuk dari proses pembuangan gas amonia dan hidrogen sulfida. Tahu dan tempe merupakan makanan yang menjadi salah satu sumber protein. Harganya yang murah menjedikan makanan ini menjadi pilihan semua lapisan masyrakat. Permintaan yang tinggi menyebabkan tumbuh pesatnya industri pengolahan tahu tempe di Indonesia khususnya di NTB. Pertubahan indudtri rumah tangga ini tidak diikuti oleh perkembangan teknologi pengolahan limbahnya. Limbah yang banyak dikeluhkan oleh masyarakat adalah limbah cair dari proses pengolahan tahu dan tempe. Tahu dan tempe merupakan makanan yang bahan baku atamanya berasal dari kedelai. Kedelai merupakan sumber daya hayati yang kaya dengan asam amino esensial yang sangat bermanfat bagi tubuh. Kadar protein pada kedelai sekitar 40-43\%. Kadar protein yang tinggi menjadi masalah jika limbah pengolahan terbuang langsung kebadan air. Masalh yang biasa timbul adalah tenbentu gas amonia dan hidrogen sulfida. Gas ini menimbul bau busuk dan bersifat racun. Dibutuhkan teknologi untuk mengatasi permasalah tersebut.

Teknik untuk mengolah limbah organik salah satunya adalah menguraikan limbah menjadi bahan organik dan mineral yang mudah diserap oleh tanaman. Mineral yang dibutuhkan oleh tumbuhan secara umum ada tiga unsur utama yaitu nitrogen $(\mathrm{N})$, fosfor (P), Kalium (K) (Burr, et al, 2011) dan (Kandari, 2012). Unsur N dibutuhkan dalam sintesis protein. Protein merupakan senyawa makromolekul yang berperan utama dalam reaksi kimia dalam tumbuhan dan hewan. Unsur $\mathrm{P}$ menjadi mineral esensial dalam rangkaian genetik dan proses transefer energi. Fosfor memegang peran penting dalam reaksi utama dalam tumbuhan yaitu proses sintesis karbohidrat yang sering disebut fotosintesis (Chen. Z, et al. 2012). Hara makro menjadi komponen paling esensial yang dibutuhkan oleh tumbuhan. Pertumbuhan optimal dan produktif tanaman ditentukan oleh tercukupinya hara makro. Hara makro yang tinggi dalam pupuk organik menjadi tuntutan utama dalam setiap sintesis pupuk organik. Pupuk organik adalah nama kolektif untuk semua jenis bahan organik asal tanaman dan hewan yang dapat dirombak menjadi hara tersedia bagi tanaman, Pada $1 \mathrm{mg} / \mathrm{gram}$ kulit buah naga merah mampu menghambat $1,02 \%$ radikal bebas dan dapat menambahkan kandungan fosfor (P) (Ayu, 2017).

$$
\text { Penelitian Makiyah }
$$

menyatakan bahwa salah satu upaya untuk mengurangi pencemaran lingkungan dari limbah cair tahu dengan cara pengolahan dan pemanfaatan limbah cair tahu sebagai pupuk cair karena dalam limbah limbah cair tahu tersebut masih memiliki bahan organik yang tinggi. Limbah cair tahu memiliki kadar N, P dan K yang sangat tinggi. Kadar $\mathrm{N}$ total, $\mathrm{P}$ dan $\mathrm{K}$ dalam air limbah tahu dicapai 43,37 mg/L, 114,36 mg/L dan 223 $\mathrm{mg} / \mathrm{L}$ (Kusumawati, 2015). Keberadaan beberapa elemen dalam air limbah industri tahu seperti $\mathrm{N}, \mathrm{P}$, dan $\mathrm{K}$ dalam jugramah tertentu diperlukan oleh tanaman untuk pertumbuhannya (Siswoyo, 2017).

Konsentrasi air limbah tahu yang pekat tepat difungsikan sebagai pupuk cair untuk tanaman kangkung darat, dimana konsentrasi air limbah tahu $15 \%$ memberikan hasil yang paling optimal khususnya terhadap berat basah kangkung darat (Aliyenah, 2015). Pemberian air limbah tahu dapat dianggap sebagai pengganti pupuk cair organik, sehingga dapat memberikan hasil yang positif terhadap pertumbuhan tanaman lada hitam (Yap, 2012).

Salah satu bahan pembuatan pupuk cair yaitu limbah tahu. Pupuk cair adalah larutan yang mengandung satu atau lebih 
pembawa unsur yang dibutuhkan tanaman yang mudah larut. Kelebihan pupuk cair adalah pada kemampuannya untuk memberikan unsur hara sesuai dengan kebutuhan tanaman. Pemberian pupuk cair juga dapat dilakukan dengan lebih merata dan kepekatannya dapat diatur dengan mudah sesuai dengan kebutuhan tanaman. Pupuk organik cair dapat berasal baik dari sisa- sisa tanaman maupun kotoran hewan, sedangkan pupuk organik padat adalah pupuk yang sebagian besar atau keseluruhannya terisi atas bahan organik yang berasal dari sisa tanaman atau kotoran hewan yang berbentuk padat. Pupuk cair akan dapat mengatasi defisiensi unsur hara dengan lebih cepat, bila dibandingkan dengan pupuk padat, Hal ini didukung oleh bentuknya yang cair sehingga mudah diserap tanah dan tanaman (Calvin, 2015).

Penelitian Jamal (2016) menyatakan Kandungan fosfor (P) pada pupuk organik cair limbah tahu sebesar 0,009\%, hasil ini belum sesuai dengan Standar Mutu Pupuk Organik Peraturan Menteri Pertanian No. 70/Permentan/SR.140/10/2011 yaitu 4-6\%. Hasil penelitian ini, kandungan unsur fosfor (P) total adalah 0,009\% lebih tinggi dari pada hasil penelitian. Penelitian Dwicaksono, et al, (2013) menyatakan bahwa limbah industeri tahu kandungan unsur fosfor (P) total adalah 0,008\% (Jamal, 2016). Kebutuhan fosfor yang sangat esensial bagi tanaman menjadi tuntutan utama dalam pupuk organik (Leonel. $\mathrm{M}$, et al. 2019). Salah satu teknik untuk menungkatkat fosfor adalah pemberian bahan organik yang kaya dengan fosfor. Salah satu tanaman yang kaya dengan fosfor adalah pisang. Pisang mengandung 34\% fosfor. Tingginya kandungan fosfor pada pisang menjadi salah satu alternatif untuk meningkatkan hara makro fofor pada pada pupuk organik cair. Melihat peran esensial fosfor dalam tumbuhan mejadi dasar utama produksi pupuk organik cair yang kaya fosfor.

\section{METODE}

Jenis penelitian yang digunakan adalah penelitian pre-Experimental, Penelitian ini dilaksanakan di Laboratorium Kimia FPMIPA IKIP Mataram dan BPTP (Balai Pengkajian Teknologi Pertanian) pada Bulan Maret Tahun 2018. Subjek penlitian ini yaitu kadar fosfor dalam pupuk cair limbah tahu.

Alat yang digunakan pada penelitian ini adalahtoples, alat saring, neraca analitik, pipet tetes, blender, labu ukur, kompor, termometer dan spektrofotometer UV-Vis. Bahan yang digunakan pada penelitian ini adalah whey tahu, filtrat buah naga merah, EM4, metanol, aquades.

Rancangan yang digunakan dalam penelitian ini adalah Rancangan Acak Lengkap (RAL) dengan dua faktor perlakuan, yaitu variasi volume filtrat buah naga merah (hylocereus poyrhizus) dan waktu fermentrasi pada pembuatan pupuk.

\section{Preparasi limbah tahu}

Limbah cair tahu yang digunakan dalam penelitian ini adalah limbah cair tahu yang didapatkan dari industri tahu di Kekalik, Mataram.

\section{Persiapan Limbah Pisang}

Limbah buah pisang dicuci kemudiandipotong kecil-kecil.

\section{Fermentasi}

Masukkan limbah cair tahu ke dalam toples sebanyak $500 \mathrm{ml}$ dan tambahkan 10 gram tape setelah itu tambahkan limbah pisang di fermentasi sesuai dengan tabel dibawah ini.

Tabel.3.1 Vaiasi Yang Digunakan

\begin{tabular}{|c|c|c|c|}
\hline \multirow{2}{*}{$\begin{array}{c}\text { Massa Limbah } \\
\text { Buah pisang }(\mathrm{X})\end{array}$} & \multicolumn{3}{|c|}{ Waktu Fermentasi (Y) } \\
\cline { 2 - 4 } & 14 hari & 28 hari & 42 hari \\
\hline $250 \mathrm{~g}$ & $\mathrm{X}_{1} \mathrm{Y}_{1}$ & $\mathrm{X}_{1} \mathrm{Y}_{2}$ & $\mathrm{X}_{1} \mathrm{Y}_{3}$ \\
\hline $500 \mathrm{~g}$ & $\mathrm{X}_{2} \mathrm{Y}_{1}$ & $\mathrm{X}_{2} \mathrm{Y}_{2}$ & $\mathrm{X}_{2} \mathrm{Y}_{3}$ \\
\hline $750 \mathrm{~g}$ & $\mathrm{X}_{3} \mathrm{Y}_{1}$ & $\mathrm{X}_{3} \mathrm{Y}_{2}$ & $\mathrm{X}_{3} \mathrm{Y}_{3}$ \\
\hline
\end{tabular}

\section{Tahap Pengujian Kadar Fosfor (P)}

a. Preparasi Sampel

Menimbang 1-2 g contoh dimasukan kedalam labu kjedahl, ditambahkan $5 \mathrm{ml}$ $\mathrm{HNO}_{3}$ dan $0,5 \mathrm{HClO}_{4}$, lalu dikocok dan dibiarkan semalam.

Dipanaskan mulai dari suhu $100^{\circ} \mathrm{c}$, setelah uap kuning habis suhu dinaikkan hingga $200^{\circ} \mathrm{c}$. Destruksi diakhiri bila sudah keluar uap putih dan cairan dalam labu tersisa sekitar $0,5 \mathrm{ml}$ didinginkan dan 
diencerkan dengan aquades dan volume ditetapkan $50 \mathrm{ml}$, kocok hingga homogen dan dibiarkan semalam atau disaring dengan kertas saring w-41 agar didapat ekstrak jernih (ekstrak A) (Eviati \& Sulaeman, 2009).

b. PembuatanPereaksi Pembangkit Warna

Pereaksi pekat, ditimbang sebanyak

$12 \mathrm{~g} \quad\left(\mathrm{NH}_{4}\right)_{6} \mathrm{Mo}_{7} \mathrm{O}_{24} .4 \mathrm{H}_{2} \mathrm{O}$ ditambahkan dengan $0,275 \mathrm{~g}$ kalium antimoniltatrat ditambah dengan $140 \mathrm{ml} \quad \mathrm{H}_{2} \mathrm{SO}_{4}$ pa kemudian diencerkan dengan aquades hingga $1000 \mathrm{ml}$. Pereaksi encer; 0,53 g asam askorbat ditambahkan $25 \mathrm{ml}$ pereaksi pekat dijadikan $500 \mathrm{ml}$ dengan air bebas ion dan dikocok (Eviati dan Sulaeman, 2009).

c. Pembuatan Kurva Kalibrasi / kurva standar

Menyiapkan 7 buah labu ukur $25 \mathrm{ml}$ untuk labu nomor 1 diisi blanko sedangkan labu 2 sampai 7 diisi larutan standar fosfor (P) 2; 4; 6; 8 dan 10 ppm masing-masing sebanyak $1 \mathrm{ml}$ kemudian ditambah pereaksi sebanyak $9 \mathrm{ml}$ setelah itu didiamkan selama 15 menit. Larutan dimasukan kedalam kuvet dan diukur absorbansinya pada panjang gelombang maksimal.

Penetapan Kadar Fosfor (P) Pada Sampel Mengambil $1 \mathrm{ml}$ ekstrak A dimasukkan kedalam labu ukur $10 \mathrm{ml}$ kemudian ditambahkan aquades hingga tanda batas kemudian dikocok sampai homogen (ekstrak B). Pipet $1 \mathrm{ml}$ ekstrak B kedalam labu ukur volume $25 \mathrm{ml}$, begitupun masing-masing deret standar fosfor (P) ditambah $9 \mathrm{ml}$ pereaksi pembangkit arna kedalam setiap contoh dan deret standar, dikocok hingga homogen. Dibiarkan 15 menit, lalu diukur dengan UV- Vis pada panjang gelombang $889 \mathrm{~nm}$.

\section{Analisis Data}

Keterangan :

$$
\text { Kadar fosfor }(\mathrm{P}) \%=\frac{\text { ppm kurva } \times V p \times F p}{\text { berat contoh } h}
$$

Ppm kurva $=$ kadar contoh yang didapat dari kurva regresi hubungan antara kadar deret standar dengan pembacaannya setelah dikurangi blanko

$\mathrm{Vp}=$ Volume pengenceran

$\mathrm{Fp}=$ faktor pengenceran

\section{HASIL DAN PEMBAHASAN}

\section{A. Hasil penelitian}

Penelitian ini dilaksanakan di Laboratorium Kimia FPMIPA IKIP Mataram dan di BPTP ( Balai Pengkajian Teknologi Pertanian ). Dalam penelitian ini, digunakan beberapa variasi volume filtrat buah naga dan waktu fermentasi. Variasi massa limbah buah pisang $250 \mathrm{~g}, 500 \mathrm{~g}, 750$ g dengan waktu fermentasi 14 hari, 28 hari dan 42 hari. Semua variasi sampel di uji mengunakan spektrofotometer UV-Vis.

Uv-Vis untuk mengetahui kadar fosfor $(\mathrm{P})$ pada pupuk cair.

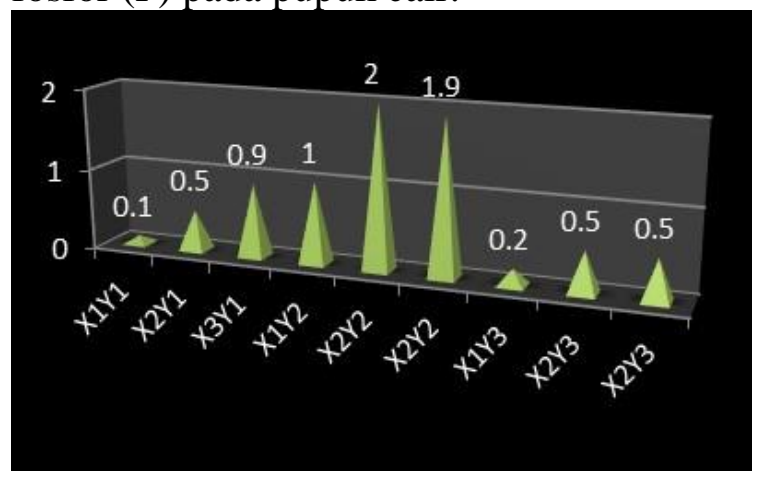

Kandungan fosfor (P) pada pupuk organik cair limbah tahu sebesar 0,009\%. Standar Mutu Pupuk Organik Peraturan Menteri Pertanian No.

70/Permentan/SR.140/10/2011 untuk kadar fosfor (P) sebesar 4-6\%. ( Jamal, 2016).

1. Hasil Analisis Kadar Fosfor (P) Whey Tahu

Sebelum fermentasi, dilakukan analisis kadar fosfor (P) untuk whey tahu dan ekstrak buah naga di Laboratorium BPTP Narmada. Hasil analisa dapat dilihat pada Tabel $4.1 \mathrm{di}$ bawah ini:

Tabel 4.1 Hasil analisis kadar fosfor (P) $\frac{\text { Sampel }}{\text { Whey Tahu }} \frac{\text { Kadar } \mathrm{P}(\%)}{0,009}$

\section{Hasil Analisis Kadar Fosfor (P)} Pupuk Organik Cair.

Penentuan kadar fosfor $(\mathrm{P})$ di Laboratorium BPTP NTB. Hasil analisa pupuk limbah cair tahu dapat dilihat pada Tabel 4.2 di bawah ini:

Tabel 4.2 Hasil dari kadar fosfor $(\mathrm{P})$ yang 
dihasilkan

\begin{tabular}{|c|c|}
\hline $\begin{array}{c}\text { volume filtrat } \\
(\mathrm{ml}) / \text { waktu fermentasi } \\
\text { (hari) }\end{array}$ & Kadar fosfor (\%) \\
\hline $\begin{array}{c}\mathrm{X}_{1} \mathrm{Y} \\
1\end{array}$ & 0,1 \\
\hline $\begin{array}{c}\mathrm{X}_{2} \mathrm{Y} \\
1\end{array}$ & 0,5 \\
\hline $\begin{array}{c}\mathrm{X}_{3} \mathrm{Y} \\
1\end{array}$ & 0,09 \\
\hline $\begin{array}{c}\mathrm{X}_{1} \mathrm{Y} \\
2\end{array}$ & 0,5 \\
\hline $\mathrm{X}_{2} \mathrm{Y}$ & 2 \\
2 & 1,9 \\
\hline $\mathrm{X}_{3} \mathrm{Y}$ & \\
\hline 2 & 0,2 \\
\hline $\mathrm{X}_{1} \mathrm{Y}$ & \\
\hline 3 & 0,5 \\
\hline $\mathrm{X}_{2} \mathrm{Y}$ & 0,5 \\
\hline 3 & \\
\hline $\mathrm{X}_{3} \mathrm{Y}_{3}$ & \\
\hline
\end{tabular}

Dapat dilihat pada tabel diatas kadar fosfor $(\mathrm{P})$ paling tinggi yaitu pada variasi $\mathrm{X}_{2} \mathrm{Y}_{2}$ sebanyak $2 \%$, pada kadar fosfor $(\mathrm{P})$ paling rendah yaitu pada variasi $\mathrm{X}_{1} \mathrm{Y}_{2}$ sebesar $0,1 \%$.

\section{B. Pembahasan}

Penambahan limbah pisang dan lama fermentasi berdampak signifikan terhadap peningkatan jumlah fosfor. Lama fermentasi 14 hari dengan massa limbah buah pisang 250 gram diperoleh konsentrasi fosfor terendah sebesar $0,1 \%$. Konsentrasi fosfor tertinggi diperoleh pada kondisi fermentasi 28 hari dan massa limbah pisang 500 gram sebesar $2 \%$. Lebih jelasnya dapat dilihat pada gambar 1 .

Konsentasi fosfor yang cukup tinggi disebabkan oleh kandungan fosfor pada kulit pisang tinggi. Hal senada ditemukan oleh (Purnomo,et al 2017) penambahan limbah pisang berpengaruh signifikan terhadap peningkatan konsentarasi fosfor pada pupuk organik. Karim, et al. 2017. melaporkan kadar Fosfat (P2O5) tertinggi terdapat pada cairan fermentasi 30 hari sebesar 2,68 \% dengan menggunakan limbah yang telah direbus dari sebelumnya
2,36 \% pada lama fermentasi 15 Hari. Menurut Gultom \& Prabatiwi (2017), adanya penurunan kadar Fosfat antara hari ke-15 dan ke-30 disebabkan karena adanya reaksi balik pada fosfat, seiring dengan berkurangnya mikroorganisme perombak

Salah satu yang menyebabkan menurunnya jumlah mikroorganime adalah meningkatnya $\mathrm{pH}$ akibat produk samping fermentasi. Produk samping fermentasi tersebut adalah asam. Meningkat jumlah asam dalam pupuk organik menyebabkan mikroorganisme menjadi mati. Matinya mikroorganisme berinfilasi terhadap menurunnya jumlah bahan organik yang akan didestruksi.

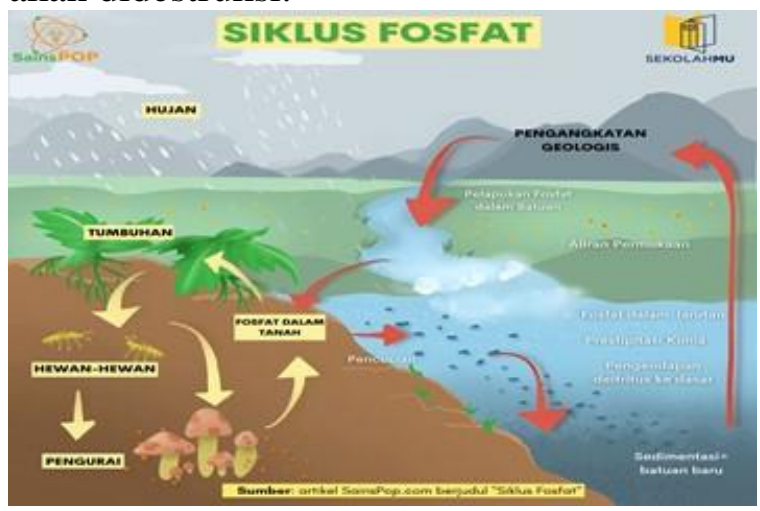

Berdasarkan gambar diatas mikroorganisme mengambil peran penting dalam siklus fosfor. Jika mikroorganisme ini tidak bisa berkembang akibat reaksi kimia yang terjadi didalam limbah organik maka pasti berdampak terhadap perobkan makromolekul senyawa organik. Sutrirna. R, et. al. 2015. Melaporkan aktivitas miroorganisme paling banyak terlihat pada $\mathrm{pH}$ 6. Dibawah dan diatas $\mathrm{pH}$ tersebut aktivitas mikroorganisme menurun. Hal ini dibuktikan dari perbedaan diameter zona bening. Berdasarkan temuan tersebut produksi samping berupa asam dalam setiap perombakan senyawa organik harus diperhatikan.

\section{Simpulan}

Terdapat pengaruh nyata lama fermentasi dan pemberian limbah pisang terhadap peningkatan konsentarsi fosfor pada pupuk organik cair dari limbah tahu. Dibutuhkan pengaturan $\mathrm{pH}$ untuk mendapatkan konsentari fosfor yang lebih 
tinggi

\section{DAFTAR PUSTAKA}

+LIMBAH+SECARA+AEROB+UNTU $\mathrm{K}+\mathrm{PEMBUATAN}+\mathrm{PUPUK}$

+ORGANIK.Diakses tanggal Desember 23 2015.jam 3:19 pm.

BURR; F.T. BARROWS; G. GAYLORD; W.R. WOLTERS. (2011.) Apparent digestibility of macronutrients and phosphorus in plantderived ingredients for Atlantic salmon, Salmo salar and Arctic charr, Salvelinus alpinus. Aquaculture Nutrition. Vol. 7. Hal. 570-577.

Dwicaksono, et. al. (2013). Effective Microorganism Pada Limbah Cair Industri Perikanan Terhadap Kualitas Pupuk Cair Organik.

Farid, S. L. (2014). Pengolahan Limbah Baglog Jamur dengan kotoran hewan ayam secara erob untuk pembuatan pupuk organic. (Online)https://www.google.co.id/ gws_r d=ssl\#q=PENGOLAHAN

Gultom, Reynad DP., Prabatiwi, RillyaK. 2017. Pemanfaatan Limbah Air Kelapa menjadi Pupuk Organik Cair Menggunakan Mikroorganisme Aspergillus niger, Pseudomonas putida dan Bioaktivator EM4. Skripsi. Departemen Teknik Kimia, Fakultas Teknologi Industri, Institut Teknologi Sepeuluh November Surabaya.

Jamal. (2016). pembuatan pupuk organik cair dari limbah tahu dengan menggunakan bioktivator effetive microorganism 4

Jawa tengah :penebar swadaya.

Kaswinarni, F. (2007). Kajian Teknis Pengolahan Limbah Padat Dan Cair Industri Tahu. Program Studi Ilmu Lingkungan Universitas Diponegoro.

Kusumawati, D. (2015). Bersahabat dengan Hewan Coba. Gadjah Mada University Press.
Yogyakarta.

Makiyah, Mujiatul. (2013).Analisis kadar n, $p$ dan $k$ Pada pupuk cair limbah tahu dengan Penambahan tanaman matahari Meksiko (thitonia diversivolia). semarang:Universitas negeri semarang.

Murbandono L.HS. (2000).membuat Kompos.

Myrasandri P., Syafila M. (2012). Degradasi senyawa organik air limbah tahu dalam anaerobic Baffled

Reactor.http://www.ftsl.itb.ac.id/w $\mathrm{p}$ -

content/uploads/2012/07/15308036 Putri-Myrasandri.pdf.Diakses pada tanggal 14 September 2017.

Nurhasan, P. B. B. (2016). Penanganan Air Limbah Pabrik Tahu. Yayasan Bina Kasta Lestari Bintarti. Semarang.

Panjuantiningrum, F. (2009). Pengaruh Pemberian Buah Naga Merah (Hylocereus polyrhizus) Terhadap Kadar Glukosa Darah Tikus Putih yang Diinduksi Aloksan, Fakultas Kedokteran Universitas Sebelas Maret, Surakarta.

Roman, M., Kaczor, A., Dobrowolski, J. C., and Baranska, M. (2013). Structural Changes of B-carotene and Some Retinoid Pharmaceuticals Induced by Environmental Factors. Journal of Molecular Structure. 1037(1) : 99108.

Rudy Sutrisna, Christina Nugroho Ekowati , Edelina Sinaga. Effect of $\mathrm{pH}$ on Production Antibacterial by Lactic Acid Bacteria From Gut Duck. Jurnal Penelitian Pertanian Terapan Vol 15 (3): 234-238.

Sudaryati, N. L. G. et al. (2007). Pemanfaatan Sedimen Perairan Tercemar Sebagai Bahan lumpur Aktiv dalam Pengolahan Limbah Cair Industri Tahu. Jurnal Ecotrophic 3(1) : 21-29. 
Utami, R. D., Yuliawati, K. M., and Safnir, L. (2015). Pengaruh Metode Ekstraksi terhadap Aktivitas Antioksidan Daun Sukun (Arthocarpus altilis (Parkinson) Fosberg). Prosiding Penelitian Spesia Unisba. 280-286.

Wididiana, B.N., S.K. Riyatmo, dan T. Higa. (1996). Tanya-Jawab Teknologi Effective Microorganisms. Jakarta : Penerbit Koperasi Karyawan Departemen Kehutanan.

Yap, Chin Ann. (2012). Impact of Different Fertilization Methods on The Soil, Yield and Growth Performance of Black Pepper (Piper Nigrum L). Malaysian Journal of Soil Science.

Zhen Chen - Shuo Chen - Gaofei Lu • Xiongwen Chen. (2012). Phosporus Limitation For the Coloni Formation. Biotechnol Lett (2012) 34:137-143. 